\title{
Влияние свинца на содержание фотосинтетических пигментов в растениях горчицы белой, обработанных клетками Bacillus subtilis
}

\section{The influence of lead on the photosynthetic pigments content in plants of white mustard treated by Bacillus subtilis cells}

\author{
Смирнова Ю. В, Курамшина 3. М. \\ Smirnova Yu. V, Kuramshina Z. M. \\ Стерлитамакский филиал ФГБОУ ВО «Бамкирский государственный университет», г. Стерлитамак, Россия. \\ E-mail:bh84@mail.ru
}

Sterlitamak branch of FSBEI HE "Bashkir State University", Sterlitamak, Russia

\begin{abstract}
Peфepam. Изучено влияние свинца на рост и содержание фотосинтетических пигментов в побегах растений Sinapis alba L., инокулированных клетками эндофитных штаммов Bacillus subtilis. Показано, что обработка семян эндофитными бациллами повышала устойчивость горчицы белой к действию свинца, что проявлялось в лучших показателях роста и содержания фотосинтетических пигментов в тканях обработанных бактериями растений.
\end{abstract}

Ключевые слова. Тяжелые металлы, фитостресс, фотосинтез, фотосинтетические пигменты, эндофиты.

Summary. The influence of lead on the growth and content of photosynthetic pigments in the shoots of Sinapis alba L. inoculated by cells of endophytic Bacillus subtilis strains was studied. It was shown that seed treatment with endophytic bacilli improves white mustard plant resistance to the toxic effect of lead, which is manifested in the best indicators of growth and content of photosynthetic pigments in the tissues of plants treated with bacteria.

Key words. Endophytes, heavy metals, phytostress, photosynthesis, photosynthetic pigments.

Свинец является одним из наиболее важных и распространенных токсичных тяжелых металлов в окружающей среде. Благодаря своим физико-химическим свойствам, таким как мягкость, пластичность, устойчивость к коррозии, он нашел широкое распространение в современной промышленности. И, как следствие, глобальная эмиссия свинца в естественные и искусственные экосистемы увеличилась. Антропогенными источниками свинца в экосистемах являются этилированное топливо, металлургия, гончарное дело, кораблестроение, утилизация аккумуляторов, ненормированное использование минеральных удобрений, особенно фосфорных, и т. д.

Повышение концентрации свинца в почве вследствие антропогенных процессов оказывает негативное влияние на растения. Общие визуальные симптомы токсичности свинца - быстрое торможение роста корней и побегов, неразвитость растений, почернение корневой системы и хлороз. Свинец нарушает минеральное питание, водный баланс, снижает активность многих ферментов, вызывает развитие окислительного стресса в растительных тканях. Под воздействием ионов свинца снижается скорость фотосинтеза, что является следствием возникающих нарушений ультраструктуры хлоропластов, угнетения синтеза хлорофилла, пластохинона и каротиноидов, затрудненного транспорта электронов, ингибирования активности ферментов цикла Кальвина, а также дефицита $\mathrm{CO}_{2}$ в результате закрывания устьиц (Nas, Ali, 2018).

В естественных условиях большинство растений живут в сообществе с различными микроорганизмами (микоризными грибами, эндофитными и ризосферными бактериями), многие из которых оказывают положительное влияние на рост, развитие и устойчивость растений к неблагоприятным факторам среды. Такими бактериями являются эндофитные штаммы Bacillus subtilis. 
Целью настоящей работы явилось изучение влияния свинца на содержание фотосинтетических пигментов в тканях побегов растений горчицы белой (Sinapis alba L.) сорта 'Рапсодия', обработанных клетками эндофитных штаммов бактерий Bacillus subtilis 26Д и 11ВM.

Семена перед посевом в почву тщательно промывали мыльным раствором и стерилизовали 96 \%- м этанолом. Для инокуляции семян использовали 20-часовую культуру бактерий Bacillus subtilis 26Д (ВНИИСХМ, №128) и 11ВМ (ВНИИСХМ, №519), выращенную на мясо-пептонном агаре при +37 ${ }^{\circ} \mathrm{C}$. Обработку семян клетками эндофитов проводили в стерильных условиях, в ламинар-боксе. Для получения препарата $B$. subtilis, бактерии отмывали $0,001 \mathrm{M}$ раствором $\mathrm{KCl}$, затем концентрацию суспензии доводили до $10^{6}$ кл/мл по оптической плотности. Расход препарата составил 20 мкл на 1 г семян. Семена контрольных растений в том же объеме обрабатывали дистиллированной водой. После обработки семена горчицы выдерживали в закрытых сосудах до полного подсыхания, затем использовали в экспериментах.

Для выращивания растений использовали пластиковые вегетационные сосуды (20 Ч 20 см) с выщелоченным черноземом. Эксперименты проводили в лабораторных условиях при искусственном освещении (12 кЛк, 16-часовом фотопериод) при температуре $18-20^{\circ} \mathrm{C}$ в течение 30 суток. Для имитации загрязнения почвы свинцом металл вносили в виде раствора соли $\mathrm{Pb}\left(\mathrm{NO}_{3}\right)_{2}$, однократно после посева семян, рассчитывая соответствующую концентрацию ионов металла (10, 1500, 3000 мг/кг почвы). Контрольные растения поливали дистиллированной водой. Измерение растений и отбор проб для определения хлорофиллов и каротиноидов проводили на 30 сутки. Экстракцию и определение содержания пигментов в растительных тканях проводили по методике, предложенной А. А. Шлык (1971). Содержание суммы хлорофиллов $a$ и $b$, каротиноидов определяли в спиртовой вытяжке ( $80 \%$ этанола), измеряя величину оптической плотности при длине волны 665, 649 и 440 нм. Эксперименты проводили не менее чем в трех биологических повторах и четырех аналитических повторностях.

В ходе проведенных нами экспериментов было отмечено, что инокулированные бактериями растения пшеницы имели более высокие ростовые показатели, чем неинокулированные, как при воздействии свинца, так и в отсутствии металла (табл. 1). Ионы свинца в низкой концентрации (10 мг/кг почвы) стимулировали рост надземной части необработанных растений Sinapis alba, высокие дозы ионов свинца в почве (1500 и 3000 мг/кг) вызывали угнетение роста неинокулированных растений. Биомасса побегов горчицы была ниже, чем в контрольном варианте, на 8,6 и 11,3 \%, соответственно для концентраций 1500 и 3000 мг/кг.

Таблица 1

Macca побегов Sinapis alba L., выращенных в почве, загрязнённой ионами свинца, г

\begin{tabular}{|c|c|c|}
\hline Концентрация $\mathrm{Pb}^{2+}$ в почве, мг/кг & Вариант & Сырая масса одного растения \\
\hline \multirow{3}{*}{0} & Не обр. & $0,85 \pm 0,04$ \\
\hline & Обр. В. sub. 26Д & $0,94 \pm 0,07$ \\
\hline & Обр. B. sub. 11BM & $0,91 \pm 0,05$ \\
\hline \multirow{3}{*}{10} & Не обр. & $0,92 \pm 0,06$ \\
\hline & Обр. B. sub. 26Д & $0,93 \pm 0,03$ \\
\hline & Обр. B. sub. 11BM & $0,90 \pm 0,04$ \\
\hline \multirow{3}{*}{1500} & Не обр. & $0,78 \pm 0,03$ \\
\hline & Обр. B. sub. 26Д & $0,85 \pm 0,02$ \\
\hline & Обр. B. sub. 11BM & $0,84 \pm 0,01$ \\
\hline \multirow{3}{*}{3000} & Не обр. & $0,76 \pm 0,05$ \\
\hline & Обр. B. sub. 26Д & $0,91 \pm 0,02$ \\
\hline & Обр. B. sub. 11BM & $0,84 \pm 0,04$ \\
\hline
\end{tabular}

Предпосевная инокуляция семян горчицы способствовала повышению устойчивости к действию свинца во всех исследованных концентрациях, что проявилось в лучших показателях роста растений. Так, растения, инокулированные B. subtilis шт. 26Д и шт. 11ВМ, при воздействии свинца в концентрации 1500 мг/кг, обладали более высокими показателями массы побегов, чем необработанные на 9,0 и 8,6 \%, при концентрации 3000 мг/кг - на 20 и 11,6 \%, соответственно для шт. 26Д и шт. 11ВМ. 
Токсическое действие свинца на растения может быть связано с угнетением процессов фотосинтеза (Nas, Ali, 2018). Однако в проведенных нами экспериментах было показано, что в присутствии свинца в почве происходило повышение содержания хлорофиллов в побегах горчицы белой (табл. 2). Подобный эффект был описан другими авторами: стимулирующее влияние свинца на рост и содержание фотосинтетических пигментов выявлено у некоторых видов растений, у более устойчивых видов подобный эффект наблюдался при использовании более высоких концентраций металла (Казнина и др., 2005).

Таблица 2

Содержание фотосинтетических пигментов в надземной части растений Sinapis alba L., выращенных в почве, загрязнённой свинцом, мг/г сырого веса

\begin{tabular}{|c|c|c|c|c|c|}
\hline $\begin{array}{c}\text { Концентрация } \\
\mathrm{Pb}^{2+} \text { в почве, } \\
\text { мг/кг }\end{array}$ & Вариант & $\begin{array}{c}\text { Содержание } \\
\text { хлорофилла } a\end{array}$ & $\begin{array}{c}\text { Содержание } \\
\text { хлорофилла } b\end{array}$ & $\begin{array}{c}\text { Содержание } \\
\text { суммы хлоро- } \\
\text { филлов } a+b\end{array}$ & $\begin{array}{c}\text { Содержание } \\
\text { каротиноидов }\end{array}$ \\
\hline \multirow{3}{*}{0} & Не обр. & $0,22 \pm 0,02$ & $0,11 \pm 0,01$ & $0,33 \pm 0,03$ & $0,070 \pm 0,001$ \\
\hline & Обр. B. sub. 26Д & $0,25 \pm 0,02$ & $0,14 \pm 0,01$ & $0,39 \pm 0,03$ & $0,075 \pm 0,001$ \\
\hline & Обр. B. sub. 11BM & $0,23 \pm 0,01$ & $0,12 \pm 0,01$ & $0,35 \pm 0,01$ & $0,076 \pm 0,005$ \\
\hline \multirow{3}{*}{10} & Не обр. & $0,24 \pm 0,02$ & $0,12 \pm 0,01$ & $0,36 \pm 0,02$ & $0,074 \pm 0,002$ \\
\hline & Обр. B. sub. 26Д & $0,26 \pm 0,02$ & $0,14 \pm 0,01$ & $0,40 \pm 0,03$ & $0,073 \pm 0,003$ \\
\hline & Oбр. B. sub. 11BM & $0,22 \pm 0,01$ & $0,12 \pm 0,01$ & $0,34 \pm 0,02$ & $0,073 \pm 0,001$ \\
\hline \multirow{3}{*}{1500} & Не обр. & $0,30 \pm 0,01$ & $0,15 \pm 0,01$ & $0,45 \pm 0,01$ & $0,080 \pm 0,006$ \\
\hline & Обр. B. sub. 26Д & $0,24 \pm 0,02$ & $0,13 \pm 0,01$ & $0,37 \pm 0,03$ & $0,079 \pm 0,004$ \\
\hline & Обр. B. sub. 11BM & $0,26 \pm 0,01$ & $0,13 \pm 0,01$ & $0,39 \pm 0,02$ & $0,076 \pm 0,005$ \\
\hline \multirow{3}{*}{3000} & Не обр. & $0,23 \pm 0,01$ & $0,12 \pm 0,01$ & $0,35 \pm 0,02$ & $0,069 \pm 0,005$ \\
\hline & Обр. B. sub. 26Д & $0,26 \pm 0,02$ & $0,13 \pm 0,01$ & $0,39 \pm 0,02$ & $0,076 \pm 0,002$ \\
\hline & Обр. B. sub. 11BM & $0,27 \pm 0,01$ & $0,13 \pm 0,01$ & $0,40 \pm 0,01$ & $0,074 \pm 0,001$ \\
\hline
\end{tabular}

Обработка семян эндофитными штаммами Bacillus subtilis шт. 26Д и 11ВМ способствовала еще большему повышению содержания хлорофилла в надземной части растений горчицы при выращивании в почве, загрязненной ионами свинца (искл.: концентрация 1500 мг/кг почвы).

Свинец оказывал влияние и на содержание в побегах горчицы каротиноидов - пигментов, входящих в состав светособирающего комплекса и выполняющих роль неферментативных антиоксидантов. Ионы свинца в концентрациях 10 и 1500 мг/кг способствовали повышению уровня каротиноидов в тканях необработанных растений горчицы. Так, при концентрации металла 10 мг/кг почвы содержание каротиноидов в побегах неинокулированных растений горчицы было выше, чем в контроле (чистой почве) на 5,7 \%, при концентрации 1500 мг/кг на 14,3 \%. Увеличение содержания каротиноидов в тканях необработанных растений, вероятно, связано с выполняемой ими специфической антиоксидантной функцией. При повышении концентрации металла в почве до 3000 мг/кг содержание каротиноидов в побегах горчицы снижалось.

В побегах растений, обработанных клетками бактерий, содержание каротиноидов при воздействии свинца в концентрации 10 и 1500 мг/кг достоверно не отличалось от необработанных растений, при концентрации металла 3000 мг/кг почвы - было выше. Так, содержание каротиноидов в побегах инокулированных шт. 26Д растений было выше на $10,1 \%$ и на 7,2 \% у обработанных шт. 11ВМ, чем в побегах необработанных растений.

Таким образом, обработка семян горчицы $S$. alba изученными эндофитными штаммами бактерий

B. subtilis способствует при воздействии свинца не только лучшем росту инокулированных растений, но и поддержанию фотосинтетических пигментов на более высоком уровне по сравнению с необработанными проростками. Протекторный эффект B. subtilis, вероятно, связан с синтезом данными микроорганизмами биологически активных веществ (фитогормонов, ферментов, антибиотиков и др.), улучшением минерального питания и структуры почвы (Егоршина и др., 2011). Устойчивость обрабо- 
танных бактериями растений к действию свинца также связана со способностью растительных клеток противостоять окислительному стрессу, сохраняя активность ферментов на определённом уровне (Курамшина и др., 2016; 2018).

\section{ЛИТЕРАТУРА}

Егоршина А. А., Хайруллин Р. М., Лукьянцев М. А., Курамшина З. М., Смирнова Ю. В. Фосфат-мобилизующая активность эндофитных штаммов Bacillus subtilis и их влияние на степень микоризации корней пшеницы // Научный журнал Сибирского федерального университета. - Краснояраск, 2011. - № 1. - С. 172-182.

Казнина Н. М., Лайдинен Г. Ф., Титов А. Ф., Таланов А. В. Влияние свинца на фотосинтетический аппарат однолетних злаков // Известия РАН. Сер. Биологическая, 2005. - № 2. - С. 184-188.

Курамшина 3. М., Смирнова Ю. В., Хайруллин Р. М. Повышение толерантности Triticum aestivum к кадмий-стрессу с помощью эндофитных штаммов Bacillus subtilis // Физиология растений, 2016. - Т. 63. - № 5. - С. 679-687.

Курамшина 3. М., Смирнова Ю. В., Хайруллин Р. М. Токсичность кадмия и никеля для растений Sinapis alba, инокулированных эндофитными штаммами Bacillus subtilis // Физиология растений, 2018. - Т. 65. - №2. - С. 133 142.

Шлык $\boldsymbol{A}$. $\boldsymbol{A}$. Определение хлорофилла и каротиноидов в экстрактах зеленых листьев // Биохимические методы в физиологии растений / Под ред. О. А. Павлиновой. - М., 1971. - С. 154-170.

Nas F. S., Ali M. The effect of lead on plants in terms of growing and biochemical parameters: a review // MOJ Eco Environ Sci, 2018. - V. 3(4). - P. 265-268. 